\title{
TINJAUAN YURIDIS TERHADAP PUTUSAN KASUS PENCEMARAN NAMA BAIK DENGAN MENGGUNAKAN SOSIAL MEDIA INSTAGRAM DITINJAU DARI PASAL 310 AYAT (3) KITAB UNDANG- UNDANG HUKUM PIDANA
}

\section{Danny Putera Christian}

(Mahasiswa Program S1 Fakultas Hukum Universitas Tarumanagara Jakarta)

(E-mail : dannypchristian@gmail.com)

\section{Dian Adriawan Daeng Tawang}

(Corresponding Author)

(Dosen Hukum Pidana Fakultas Hukum Universitas Tarumanagara dan Fakultas Hukum Universitas Trisakti, Meraih Sarjana Hukum dari Fakultas Hukum Universitas Hasanuddin Makassar, Magister Hukum dari Fakultas Hukum Universitas Hasanuddin Makassar, Doktor Hukum dari Fakultas Hukum Universitas Hasanuddin Makassar)

(E-mail :dian.adriawan@gmail.com)

\begin{abstract}
The regulation of defamation is stated in the Indonesia Criminal Code, specifically it's stated on the article 310. However, the legal rules of defamation by using social media are specifically regulated in Undang-UndangNo.19 Year 2016 About the Amendment of Undang-Undang No.11 Year 2008 About Information And Electronic Transactions. In a thesis that written by the author, the author did an analysis of the actions that have been done by a defendant who deliberately perform an action that meets the element of offense in Article 27 Paragraph (3) of UndangUndang No.19 Year 2016 on Amendment to Law No. 11 Year 2008 About Information And Electronic Transactions. The acts committed by the defendant shall not be subject to juridical sanctions, since the criminal law also applies the reasons for the criminal offense both for justification and for reasons of forgiveness. The act committed by the defendant in Decision No.1047 / Pid.Sus / PN.JKT.SEL was analyzed as justification because the defendant committed the act to defend himself, as regulated in Article 310 Paragraph (3) of the Criminal Code. The research method whichused by the author is normative research supported by conducting interviews to cyber crime experts.
\end{abstract}

Keywords :Social Media, Defamation, and Justification Reasons 


\section{PENDAHULUAN}

\section{A. Latar Belakang}

Perkembangan informasi dan teknologi pada era globalisasi berkembang dengan pesat. Manusia terus berusaha untuk melakukan berbagai inovasi dalam rangka mengembangkan dan menyempurnakan beraneka ragam jenis teknologi sebagai sarana penunjang yang dapat membantu berbagai aspek dalam kehidupan manusia sehari-hari. Manusia berinovasi dengan cara melakukan elaborasi terhadap teknologi satu dengan teknologi yang lainnya sehingga dewasa ini teknologi mengalami perkembangan yang sangat pesat dan signifikan serta telah mengubah peranan teknologi tersebut menjadi suatu kebutuhan yang bersifat primer bagi kehidupan manusia. Dengan adanya hal tersebut maka dapat dikatakan bahwa kebutuhan manusia akan teknologi terus meningkat setiap harinya.

Teknologi memunculkan banyak dampak yang bersifat positif maupun yang bersifat negatif. Dengan adanya teknologi-teknologi terbaru, jika dilihat dari dampak negatifnya banyak menimbulkan berbagai macam kejahatan yang bervariasi. Salah satu kejahatan dengan menggunakan teknologi yang kita kenal yaitu kejahatan cybercrime. Beberapa ahli mengemukakan pendapatnya mengenai cybercrime karena cybercrime kerap disamakan dengan computer crime. Menurut The U.S. Department of Justice definisi cybercrime adalah "Any illegal act requiring knowledge of computer technology for its perpetration, investigation, or prosecution". Hal serupa didefinisikan juga oleh Organization of European Community Development, yang mendefinisikan computer crime sebagai : "Any illegal, unehtical or unauthorized behavior relating to the automatic processing and/ or the transmission of data". Sementara menurut Andi Hamzah kejahatan komputer mempunyai pengertian sebagai berikut : "Kejahatan di bidang komputer yang secara umum dapat diartikan sebagai penggunaan komputer secara illegal". 1

1 http://business-law.binus.ac.id/2016/07/31/kejahatan-dengan-menggunakan-saranateknologi-informasi/, 12 Agustus 2017. 
Variasi kejahatan cybercrime semakin banyak bermunculan karena adanya teknologi berupa internet. Internet atau kepanjangan dari InterconnectionNetworking yang artinya sekumpulan jaringan dari seluruh dunia yang menghubungkan jutaan perusahaan, badan pemerintahan, institusi pendidikan dan orang-perorangan. ${ }^{2}$ Internet pertama kalinya ditemukan oleh Leonard Kleinrock dari Massachutts Institute of Technology. ${ }^{3}$ Internet pertama kali digunakan pada tahun 1969 ketika Departemen Pertahanan Amerika, U.S. Defense Advanced Research Projects Agency memutuskan untuk mengadakan riset tentang bagaimana menghubungkan sejumlah komputer sehingga membentuk jaringan organik. ${ }^{4}$ Pada awalnya pengembangan jaringan yang bersifat global ini hanya dimanfaatkan oleh angkatan bersenjata Amerika Serikat untuk mengembangkan senjata nuklir, ${ }^{5}$ namun lama kelamaan dunia pendidikan dirasa perlu untuk mempelajari dan mengembangkan jaringan ini. Tahun 1970 internet mulai diperkenalkan secara luas di Amerika Serikat dan terus berkembang pesat ke Negara-negara lainnya sampai dengan sekarang.

Indonesia merupakan salah satu negara yang mengalami kemajuan dalam hal penggunaan internet, karena dengan adanya internet pertukaran informasi dapat dilakukan secara cepat, akurat, dan membutuhkan biaya yang cukup murah. Kehadiran internetjuga telah membawa dampak yang sangat signifikan pada perkembangan ilmu pengetahuan dan teknologi pada saat ini. Teknologi ini mampu untuk membantu pemerintah dalam mencerdaskan kehidupan bangsa sebagai bagian dari masyarakat dan informasi dunia, membawa manusia kepada tingkat kualitas kehidupan yang lebih baik, serta dapat meningkatkan efektivitas dan efisiensi dalam pelayanan publik.Akan tetapi, dalam waktu bersamaan

\footnotetext{
${ }^{2}$ Shelly et al., Discovering Computers : Menjelajah Dunia Komputer Fundamental Edisi 3. (Jakarta: Salemba Infotek, 2008), hal.9.

3 Agus Raharjo, Cyber Crime Pemahaman Dan Upaya Pencegahan Kejahatan Berteknologi, (Cetakan pertama). (Bandung: Citra Aditya Bakti,2002), hal.62.

4 OPINI, "Sejarah dan Perkembangan Internet", http://teknologi.kompasiana.com/internet/2014/07/02/sejarah-dan-perkembanganinternet661863.html, 12 Agustus 2017.

5 Anonim, "Makalah Sejarah Perkembangan Internet di Dunia", https://docs.google.com/document/d/1qCNWAFBXQvyfk2fygSB00o6w8n9z-

VNxNUFrTs2Osvk/edit?pli=1\#heading=h.gjdgxs, 12 Agustus 2017.
} 
terdapat juga potensi permasalahan-permasalahan yang besar sebagai akibat dari penyalahgunaan teknologi informasi.

Perkembangan penggunaan internet di Indonesia memang tidak pernah terduga sebelumnya, beberapa tahun yang lalu internet hanya dikenal dan digunakan oleh segelintir orang yang mempunyai kepentingan tertentu. Namun, dalam tahun terakhir ini pengguna layanan internet meningkat secara pesat, bahkan secara faktual angka pengguna internet di Indonesia mencapai 132,7 juta jiwa, dengan kata lain 51,8\% dari jumlah penduduk di Indonesia merupakan pengguna layanan internet secara aktif. Data tersebut merupakan data efektif yang dihimpun oleh Asosiasi Penyelenggara Jaringan Internet Indonesia per-tahun 2016. ${ }^{6}$ Signifikansi perkembangan teknologi komputer dengan telematika mengharuskan filosofi perlunya aturan dan/atau norma menjadi sesuatu yang tidak dapat diabaikan lagi. Sejatinya, Indonesia pun sudah cukup lama mempunyai peraturan perundang-undangan yang mengatur mengenai Informasi dan Transaksi Elektronik, yang baru diperbaharui tahun 2016 silam menjadi menjadi UndangUndang No.19 Tahun 2016 tentang Perubahan Atas Undang-Undang No.11 Tahun 2008 tentang Informasi dan Transaksi Elektronik. Dalam Pasal 3 ayat (1) Undang-Undang No. 19 Tahun 2016 disebutkan bahwa asas-asas pemanfaatan teknologi informasi dan komunikasi harus dilakukan berdasarkan asas kepastian hukum, asas manfaat, itikad baik, kehati-hatian, dan kebebasan untuk memilih teknologi atau netral tekonologi.

Oleh sebab itulah penggunaan internetsebagai produk dari teknologi informasi dan komunikasi di Indonesia pun mempunyai batas kewajaran tertentu dalam segi penggunaannya.

Sambungan koneksi internet dapat digunakan sebagai sarana untuk mengakses sosial media. Manusia menggunakan sosial media untuk berkomunikasi dan berbagi kabar dan informasi terhadap sesamanya. Dengan adanya sosial media, maka manusia dapat secara mudah untuk terhubung antara satu dengan lainnya, tanpa adanya batasan ruang dengan waktu. Hal tersebut

${ }^{6}$ http://tekno.kompas.com/read/2016/10/24/15064727/2016.pengguna.internet.di.indonesia. capai.132.juta, 12 Agustus 2017. 
memunculkan istilah baru yaitu cyberspace. ${ }^{7}$ Salah satu sosial media yang sekarang sedang populer dan jumlah pemakainya sangat banyak di Indonesia adalah Instagram. Instagram adalah sebuah sosial media yang dapat diakses melalui smartphone berbasis iOS maupun android. Kegunaan Instagram sendiri adalah untuk berbagi foto dan video yang memungkinkan pengguna Instagram untuk mengambil foto dan video, mengaplikasikan filter digital dalam foto atau video yang diunggah, dan membagikannya ke berbagai sosial media. Dengan demikian, tiap individu pun dapat dengan mudahnya berbagi kabar dan informasi terhadap sesamanya. Aplikasi Instagram juga dimanfaatkan oleh beberapa pemakainya untuk berjualan dengan basis online. Karena manusia semakin mudah terhubung antara satu dengan lainnya tanpa adanya batasan ruang dan waktu tertentu, perlu disadari bahwa eksistensi hukum tetap hadir,mengatur,serta membatasi hal-hal yang bersifat khusus dalam kehidupan manusia.

Di dalam suatu sistem masyarakat akan selalu ada sistem hukum yang berlaku, karena sebagai mahluk sosial (zoon politicon), manusia tidak dapat menghindari adanya bentrokan-bentrokan kepentingan di antara mereka. ${ }^{8}$ Oleh karena itu, asas ubi societas ibi ius pun berlaku untuk mengatur kehidupan manusia. ${ }^{9}$ Perubahan-perubahan yang terjadi di dalam masyarakat mengubah pula dasar-dasar nilai hukum, dimana dasar-dasar hukum dipengaruhi oleh dasar politik, ekonomi, kehidupan sosial, dan kesusilaan dimana hukum berperan untuk memberikan atau menciptakan suatu ketertiban. ${ }^{10}$ Mengingat dengan banyaknya aspek perubahan yang terjadi dalam peradaban manusia, internet berpeluang untuk menciptakan kejahatan-kejahatan baru yang sebelumnya belum dikenal oleh masyarakat luas, internet juga memunculkan kejahatan yang memang sebelumnya sudah dikenal masyarakat namun dalam pelaksanaannya menjadi lebih canggih karena terbantu dengan adanya internet.

\footnotetext{
${ }^{7}$ Jeff Sallesky, Spiritualitas Cyberspace, Bagaimana Teknologi Komputer Mempengaruhi Kehidupan Keberagaman Manusia, (Bandung: Mizan, 1999), hal.9.

${ }^{8}$ Bambang Sutiyoso, Metode Penelitian Hukum (Edisi Revisi), (Yogyakarta: UII Press, 2015), hal. 2.

${ }^{9}$ Sudikno Mertokusumo, Mengenal Hukum Suatu Pengantar (Edisi Revisi), (Yogyakarta: Cahaya Atma Pustaka, 2010), hal. 35.

${ }^{10}$ Soetiksno, Filsafat Hukum Bagian 1, (Jakarta: Balai Pustaka,2013), hal. 19.
} 
Salah satu bentuk tindak pidana yang dalam pelaksanaannya semakin mutakhir untuk dilakukan dengan menggunakan layanan internet di Indonesia adalah tindak pidana penghinaan atau pencemaran nama baik yang dilakukan oleh individu terhadap individu maupun kelompok yang lain. Tindak pidana penghinaan (beleediging) adalah penyerangan terhadap martabat kehormatan dan nama baik orang bersifat pribadi maupun komunal yang menimbulkan perasaan malu, ketersinggungan, tercemar atau terhina, melahirkan rasa tidak senang, kebencian, tidak puas, sakit hati, amarah, dan penderitaan yang menyiksa batin orang lain. ${ }^{11}$ Hal tersebut telah dirumuskan di dalam Pasal 310 KUHP. Tindak pidana penghinaan atau beleediging yang dibentuk oleh pembentuk Undangundang baik yang bersifat umum maupun yang bersifat khusus ditujukan untuk memberikan perlindungan terhadap kepentingan umum,khususnya rasa harga diri mengenai kehormatan (eer) dan rasa harga diri mengenai nama baik (goeden naam) seseorang. ${ }^{12}$

Hal-hal yang dikomunikasikan atau dipublikasikan melalui internet adalah merupakan tindak pidana penghinaan atau pencemaran nama baik apabila hal tersebut adalah tidak benar adanya bagi pihak korban, baik itu merupakan itu yang merusak reputasi ataupun yang membawa kerugian material bagi pihak korban. Publikasi atau komunikasi tentang diri pihak lain dapat dikatakan pencemaran nama baik atau penghinaan, baik dilakukan dengan kata-kata atau tulisan yang terang-terangan maupun dengan bentuk yang tersembunyi namun mengandung konotasi yang merusak reputasi seseorang atau badan atau instansi tertentu. Tindak pidana pencemaraan berbasis Informasi dan Transaksi Elektronik diatur dalam Pasal 27 Ayat (3) Undang-Undang No.19 Tahun 2016 yang menyatakan bahwa "Setiap orang dengan sengaja dan tanpa hak mendistribusikan dan/atau mentransmisikan dan/atau membuat dapat diaksesnya Informasi Elektronik dan/atau Dokumen Elektronik yang memiliki muatan penghinaan dan/atau pencemaran nama baik.',

\footnotetext{
${ }^{11}$ Adami Chazawi, Hukum Pidana Positif Penghinaan (Edisi Revisi), (Malang: Media Nusantara Creative, 2016), hal. 1.

${ }^{12}$ Ibid., hal. 3.
} 
Tindak pidana pencemaran nama baik yang dilakukan menggunakan sosial media Instagram pernah dilakukan oleh seorang netizen bernama Febri Matondang alias Alvin Matondang terhadap public figure Bella Shofie. Alvin Matondang mengambil video rekaman wawancara antara Bella Shofie dengan infotainment televisi swasta. Dalam video rekaman tersebut, tampak Bella Shofie sedang diwawancara oleh jurnalis infotainment televisi swasta mengenai perannya sebagai seorang perempuan dengan bahasa Batak yang kental dan khas dalam sebuah sinetron. Dalam wawancara dengan para jurnalis infotainment televisi swasta tersebut kemudian Bella Shofie menyatakan bahwa orang banyak bisa illfeelterhadap dirinya jikalau ia berbicara menggunakan bahasa Batak. Bella Shofie mengemukakan pernyataan yang berisi demikian "Enggak lah, nanti orang-orang illfeel lagi lihat saya, cantik-cantik begini ngomongnya Batak..." Hal tersebut membuat Febri Matondang alias Alvin Matondang yang merupakan salah satu bagian dari masyarakat Indonesia yang berasal dari suku Batak tidak terima atas pernyataan yang dikemukakan oleh Bella Shofie dalam wawancara tersebut, dimana Bella Shofie mengungkapkan seolah-olah Bahasa Batak dapat membuat orang banyak menjadi illfeel. Alvin melakukan proses penyatuan terhadap cuplikan video wawancara antara Bella Shofie dengan awak media infotainment tersebut dan menyatukannya dengan video rekaman reaksi Alvin setelah melihat pernyataan Bella Shofie.

Dalam video rekaman yang dibuat oleh Alvin, Alvin memberikan pernyataan "Anjing kali kau ya, gak sejelek itu Batak, tahu kau !! Babi kau memang. Eh daki selangkangan kau dengar ya, tidak sejelek itu Batak, tahu kau !" yang kemudian video tersebut diunggah ke akun sosial media Instagram pribadi miliknya @alvin_mtd. Karena merasa nama baiknya dicemarkan oleh Alvin Matondang, pada akhirnya Bella Shofie melaporkan perbuatan yang dilakukan oleh Alvin Matondang ke Polda Metro Jaya bulan Desember Tahun 2015. ${ }^{13}$ 13) Delik aduan diproses, persidangan telah berjalan, dan hakim menjatuhkan Pasal 27 ayat (3) Undang-Undang No. 19 Tahun 2016 terhadap 
Alvin Matondang yang kemudian Alvin mendapatkan sanksi yuridis berupa pidana kurungan selama 6 (enam) bulan lamanya.

Pernyataan yang telah dikemukakan oleh Bella Shofie bahwa berbicara dengan bahasa Batak dapat membuat orang-orang illfeel.Berdasarkan unsur delik yang ada dalam Pasal 156 Kitab Undang-Undang Hukum Pidana, maka pernyataan itu telah memenuhi unsur delik yaitu unsur merendahkan. Hal ini diperkuat dengan beberapa teori pendukung yang akan dikemukakan dalam bagian pembahasan. Menurut Oxford Advanced Learner Dictionary illfeel diartikan sebagai kata sifat yang merepresentasikan perasaan amarah atau jijik terhadap sesuatu yang dikategorikan sebagai orang,kelompok,maupun terhadap benda tertentu.

Dalam ilmu hukum pidana mengenal adanya teori sebab-akibat atau kausalitas yang merupakan hubungan antara satu peristiwa dengan peristiwa lainnya dalam kehidupan manusia. Vonburi dalam teorinya yaitu teori condicio sine qua non mengemukakan bahwa semua faktor atau syarat yang turut serta menyebabkan munculnya suatu akibat dan yang tidak dapat dihilangkan dari rangkaian faktor-faktor yang bersangkutan harus dianggap sebagai penyebab dari akibat yang dihasilkan. ${ }^{14}$

Terwujudnya suatu tindak pidana tidak selalu dijatuhkan sanksi pidana terhadap pelaku tindak pidana. Undang-undang telah memberikan dasar-dasar yang meniadakan pidana. Adanya aturan ini membuktikan bahwa UndangUndang memisahkan antara tindak pidana dengan pelaku tindak pidana. Pembentuk undang-undang membuat aturan ini bertujuar untuk mencapai derajat keadilan yang setinggi-tingginya. Ada banyak faktor yang bersifat objektif maupun bersifat subjektif yang memicu atau mempengaruhi seseorang untuk merealisasikan sutu perbuatan yang tidak diperkenankan oleh undang-undang. ${ }^{15}$ Pernyataan yang dikemukakan oleh Bella Shofie merupakan faktor penyebab adanya reaksi pembelaan terdakwa terhadap dirinya sendiri yang merupakan hal. 177.

${ }^{14}$ Andi Hamzah, Asas-Asas Hukum Pidana, Cetakan ke-4. (Jakarta: Rineka Cipta, 2014),

${ }^{15}$ Adami Chazawi, Pelajaran Hukum Pidana, (Jakarta: Raja Grafindo Persada, 2011), hal. 15. 
bagian dari suku Batak yang diungkapkannya melalui video yang diunggahnya ke dalam akun sosial media Instagram pribadi miliknya.

Unsur orang banyak atau masyarakat umum yang berada dalam syarat pertama alasan demi kepentingan umum, orang banyak atau masyarakat umum di Indonesia terdiri dari berbagai kumpulan individu yang berasal dari latar belakang yang beragam. Suku Batak merupakan bagian dari masyarakat umum di Indonesia yang mempunyai kebudayaan, adat-istiadat, dan bahasa sebagai satu kesatuan yang utuh. Sedangkan untuk dapat mengajukan alasan untuk membela diri hanya dapat dilakukan apabila ada serangan yang dilakukan oleh orang lain yang bersifat melawan hukum dan merugikan kepentingan hukum, perwujudannya ia menuduhkan hal tertentu yang menghinakan orang lain, selain itu untuk memulihkan hak dan kepentingan hukum yang telah dilanggar oleh orang lain.

Berdasarkan uraian yang telah diuraikan diatas, oleh karenanya dilakukan penulisan jurnal mahasiswa untuk melakukan tinjauan dan menjelaskan lebih lanjut mengenai korelasi aturan hukum dalam Pasal 310 Ayat (3) Kitab UndangUndang Hukum Pidana terhadap putusan kasus pencemaran nama baik yang dilakukan dengan menggunakan sosial media Instagram.

\section{B. Perumusan Masalah}

Berdasarkan latar belakang yang telah diuraikan sebelumnya, maka untuk lebih memfokuskan penulisan jurnal mahasiswa ini dirumuskan permasalahan Bagaimana tinjauan terhadap perbuatan yang dilakukan oleh terdakwa dalam putusan No.1047/Pid.Sus/2016/PN JKT.SEL jika ditinjau dari Pasal 310 ayat (3) Kitab Undang-Undang Hukum Pidana?

\section{Metode Analisis}

Metode yang digunakan dalam studi ini adalah penelitian hukum normatif (normative legal research), yaitu studi yang dilakukan dengan cara mengkaji peraturan perundang-undangan yang berlaku atau diterapkan pada permasalahan hukum yang sedang diteliti. Penelitian normatif juga disebut sebagai penelitian doktrinal, yaitu penelitian yang objek kajiannya adalah dokumen peraturan 
perundang-undangan dan bahan pustaka (Soekanto, 2003). Metode ini dipilih karena objek kajian studi adalah Putusan Pengadilan No.1047/Pid.Sus/PN.JKT.SEL yang dianalisis berdasarkan peraturan dalam Undang-Undang No. 19 Tahun 2016 tentang Perubahan Atas Undang-Undang No. 11 Tahun 2008 dan Kitab Undang-Undang Hukum Pidana, dimana dalam studi ini dimaksudkan untuk memberikan penjelasan mengenai tinjauan yang telah dilakukan.

\section{PEMBAHASAN}

\section{A. Kasus Posisi}

Kronologikasus pencemaran nama baik yang melibatkan Febri Matondang alias Alvin Matondang dengan public figure Bella Shofie bermula ketika Bella Shofie sedang diwawancara oleh jurnalisinfotainment televisi swasta mengenai keterlibatan dirinya dalam salah satu film baru. Dalam wawancara terrsebut, Bella Shofie menceritakan mengenai peranan dirinya dalam film tersebut, ia memerankan peran sebagai seorang wanita Batak dengan bahasa dan budaya Batak yang kental.

Setelah beberapa pertanyaan yang diajukan oleh jurnalis infotainment televisi swasta dikemukakan, Bella Shofie menyatakan bahwa dirinya tidak akan lagi mau memerankan peran sebagai wanita Batak dengan aksen dan bahasa Batak dan mengemukakan pernyataan bahwa "Enggak lah, nanti orang-orang illfeel lagi dengan saya, cantik-cantik begini kok ngomongnya Bahasa Batak." Ujar Bella Shofie sambil tertawa menanggapi pertanyaan yang diajukan oleh jurnalis infotainment televisi swasta tersebut.

Seorang pemuda yang berasal dari suku Batak bernama asli Febri Matondang alias Alvin Matondang merasa tersinggung dengan pernyataan yang telah dikemukakan oleh Bella Shofie. Menurut Alvin Matondang, bahasa Batak merupakan salah satu bagian dari kekayaan budaya Indonesia Alvin Matondang 
tidak terima atas pernyataan Bella Shofie yang menyatakan bahwa dengan menggunakan Bahasa Batak dapat membuat masyarakat luas menjadi illfeel. Kata illfeel sendiri merupakan kata sifat yang berasal dari bahasa Inggris yang apabila diterjemahkan ke dalam bahasa Indonesia berarti perasaan muak atau jijik terhadap suatu hal.

Alvin Matondang mengambil cuplikan video wawancara antara Bella Shofie dengan pihak infotainment televisi swasta tersebut. Ia memotong video tersebut pada detik-detik Bella Shofie mengemukakan pendapatnya mengenai menggunakan Bahasa Batak dapat membuat masyarakat luas menjadi illfeel. setelah itu, ia menyatukan video hasil cuplikan wawancara tersebut dengan video yang dibuatnya sendiri. Video yang dibuatnya sendiri berisi peringatan terhadap Bella Shofie, dimana Alvin mengemukakan pendapat demikian : “Anjing kali kau ya, gak sejelek itu Batak tahu kau! Babi kau memang. Hai daki selangkangan, kau dengar ya. bangga aku jadi orang Batak, tahu kau!’ lalu mengunggah video tersebut ke akun sosial media Instagram miliknya.

Alvin Matondang melakukan perbuatan itu lantaran karena ia kecewa dan tidak terima dengan pernyataan yang dikemukakan oleh Bella Shofie, serta ia juga menjelaskan bahwa bahasa Batak tidak jelek atau buruk sebagaimana yang telah diujarkan oleh Bella Shofie. ${ }^{16}$ Akan tetapi, kata-kata yang dikemukakan oleh Alvin dalam video yang diunggahnya di sosial media Instagaram pribadi miliknya mengandung substansi delik penghinaan terhadap seseorang yang diatur dalam Pasal 27 ayat (3) Undang-Undang No.19 Tahun 2016. ${ }^{17}$

Atas unggahan video yang diunggah oleh Alvin ke sosial media Instagramnya tersebut, Bella Shofie melaporkan Alvin ke Polda Metro Jaya ${ }^{18}$ yang kemudian atas dasar dari laporan tersebut kasus ini dilanjutkan ke tahap

\footnotetext{
${ }^{16}$ https://www.bintang.com/celeb/read/2373417/versus-bella-shofie-alvin-matondang-sayabukan-haters, diakses 22 April 2018.

${ }^{17}$ Indonesia, Undang-Undang Nomor 11 Tahun 2008 sebagaimana telah diubah dengan Undang-Undang Nomor 19 Tahun 2016 tentang Perubahan Atas Undang-Undang Nomor 11 Tahun 2008 Tentang Informasi dan Transaksi Elektronik, Pasal 27 Ayat (3). "Setiap orang dengan sengaja dan tanpa hak mendistribusikan dan/ atau membuat dapat diaksesnya Informasi Elektronik dan/ atau Dokumen Elektronik yang memiliki muatan penghinaan dan/ atau pencemaran nama baik".

${ }^{18}$ https://nasional.kompas.com/read/2015/09/15/142945410/Bella.Shofie.Laporkan.Hater.ke .Polda.Metro.Jaya, diakses 23 April 2018 .
} 
persidangan yang pada akhirnya hakim memutuskan bahwa Alvin Matondang bersalah berdasarkan Pasal 27 ayat (3) Undang-Undang No.19 Tahun 2016 dan membebankan sanksi pidana selama 8 (delapan) bulan penjara dan denda sebesar Rp.100.000.000,00 (seratus juta rupiah).

\section{B. Korelasi antara Pasal 310 ayat (3) Kitab Undang-Undang Hukum Pidana dengan Pasal 27 ayat (3) Undang-Undang No.19 Tahun 2016 Dalam Putusan Kasus Pencemaran Nama Baik No.1047/Pid.Sus/PN.JKT.SEL}

Secara harafiah, apa yang dimaksud sebagai suatu tindak pidana merupakan suatu perbuatan tidak boleh dilanggar oleh siapapun, dan apabila hal tersebut dilanggar maka pelakunya akan mendapatkan sanksi yang jelas dan tegas sesuai dengan pasal yang berlaku dalam Kitab Undang-Undang Hukum Pidana. Berdasarkan jenis-jenis tindak pidana yang diatur dalam Kitab Undang-Undang Hukum Pidana, terdapat jenis tindak pidana yang dapat dikenakan sanksi terhadap pelaku tindak pidana apabila adanya pengaduan dari pihak yang merasa dirugikan. Hal ini diatur dalam BAB VII Kitab Undang-Undang Hukum Pidana tentang mengajukan dan menarik kembali pengaduan dalam hal kejahatan-kejahatan yang hanya dapat dituntut berdasarkan adanya pengaduan.

Salah satu contoh tindak pidana aduan adalah tindak pidana pencemaran nama baik. Indikator suatu perbuatan dapat dikategorikan sebagai suatu tindak pidana pencemaran nama baik belum dapat dirumuskan secara jelas dan mutlak karena adanya faktor-faktor pendukung yang harus dicermati. Hal-hal yang hendak dilindungi dalam suatu tindak pidana pencemaran nama baik atau penghinaan yang dilakukan oleh salah satu pihak terhadap pihak yang lainnya adalah kewajiban agar setiap manusia dapat menghormati sesamanya berdasarkan perspektif kehormatan dan nama baiknya dimata orang lain. Tindak pidana yang berkaitan dengan suatu kepentingan hukum berupa kehormatan seseorang antara lain tindak pidana yang telah diatur dalam Buku II BAB XVI Kitab UndangUndang Hukum Pidana tentang “penghinaan”, yang meliputi Pasal 310 sampai dengan Pasal 321 Kitab Undang-Undang Hukum Pidana. 
Aturan pokok yang mengatur mengenai tindak pidana pencemaran nama baik diatur dalam Pasal 310 Kitab Undang-Undang Hukum Pidana, dimana aturan dari pasal tersebut mengancam adanya suatu sanksi pidana terhadap barang siapa yang dengan sengaja menyerang kehormatan atau nama baik seseorang dengan mengujarkan suatu hal yang bersifat buruk, negatif atau memalukan dengan maksud yang jelas agar hal itu dapat diketahui oleh khalayak umum, sebagaimana hal-hal yang bersifat menyerang kehormatan terhadap seseorang itu diatur dalam ayat sebelumnya, yaitu dalam Pasal 310 ayat (1) Kitab Undang-Undang Hukum Pidana. Apabila tindak pidana pencemaran nama baik tersebut dilakukan dengan tulisan atau gambar yang disiarkan dan atau dipertunjukkan di muka umum, maka tindak pidana tersebut diatur dalam Pasal 310 ayat (2) Kitab Undang-Undang Hukum Pidana.

Pasal 310 ayat (1) dan Pasal 310 ayat (2) Kitab Undang-Undang Hukum Pidana yang telah diuraikan secara singkat dan jelas diatas, diterjemahkan oleh Tim Penerjemah Badan Pembinaan Hukum Nasional (BPHN) demikian :

1. Barangsiapa dengan sengaja menyerang kehormatan atau nama baik seseorang dengan menuduhkan sesuatu hal, yang maksudnya terang supaya hal itu diketahui oleh umum, maka diancam karena pencemaran dengan pidana penjara paling lama 9 (sembilan) bulan atau pidana denda paling banyak empat ribu lima ratus rupiah.

2. Jika hal itu dilakukan dengan tulisan atau gambaran yang disiarkan, dipertunjukkan atau ditempelkan di muka umum, maka diancam karena pencemaran tertulis dengan pidana penjara paling lama satu tahun empat bulan atau dengan pidana denda paling banyak empat ribu lima ratus rupiah.

Penerjemahan yang telah diterjemahkan oleh Badan Pembinaan Hukum Nasional tersebut menjelaskan bahwa istilah pencemaran dan pencemaran tertulis untuk menerjemahkan istilah Bahasa Belanda smaad mengacu pada Pasal 310 ayat (1) Kitab Undang-Undang Hukum Pidana sedangkan istilah smaadschrift mengacu pada Pasal 310 ayat (2) Kitab Undang-Undang Hukum Pidana. ${ }^{19}$

19 Tim Penerjemah BPHN, Kitab Undang-Undang Hukum Pidana, Sinar Harapan, (Jakarta: Sinar Harapan, 1983), hal. 125. 
Terjemahan lain juga telah dilakukan oleh P.A.F Lamintang dan juga oleh C.D. Samosir, yang menerjemahkan smaad sebagai suatu penistaan yang dilakukan secara lisan sedangkan smaadscrift sebagai suatu penistaan dengan tulisan, dimana Pasal 310 ayat (1) dan Pasal 310 ayat (2) Kitab Undang-Undang Hukum Pidana diterjemahkan sebagai berikut :

1. Barangsiapa dengan sengaja menyerang kehormatan nama baik orang lain dengan menuduh orang itu telah melakukan suatu perbuatan tertentu dengan maksud yang nyata agar tuduhan tersebut diketahui oleh orang banyak, karena telah menista orang lain secara lisan, maka dihukum dengan hukuman penjara selama-lamanya 9 (sembilan) bulan atau dengan hukuman denda setinggi-tingginya empat ribu lima ratus rupiah.

2. Apabila perbuatan itu dilakukan dengan cara menyebarluaskan, mempertunjukkan secara terbuka atau dengan menempelkan tulisan atau gambar, maka pelakunya salah telah menista dengan tulisan, dihukum dengan hukuman penjara selama-lamanya 1 (satu) tahun dan empat bulan atau dengan hukuman denda setinggi-tingginya empat ribu lima ratus rupiah. $^{20}$

Zaman sekarang keberadaan media elektronik seperti sosial media sering kali dimanfaatkan oleh segelintir orang untuk melakukan tindak pidana pencemaran nama baik. Pemanfaatan sistem teknologi informasi dan komunikasi telah banyak mengubah perilaku masyarakat dan peradaban manusia secara global. Hal tersebut juga berdampak pada tidak adanya batas ruang (borderless) antara orang satu dengan orang yang lainnya, selain itu perkembangan tersebut juga berdampak pada adanya perubahan pola perilaku sosial, ekonomi, serta aspek kebudayaan yang berubah secara signifikan dan dalam tempo waktu yang sangat cepat. Namun demikian teknologi informasi dan komunikasi juga menimbulkan berbagai macam permasalahan dalam penerapannya.

Berdasarkan data dan analisis yang telah dilakukan, dengan adanya kemajuan teknologi infomasi dan komunikasi saat ini menjadi seperti dua sisi mata uang logam, karena selain berkontribusi pada hal-hal yang bersifat kontributif terhadap peningkatan kesejahteraan peradaban manusia, kemajuan dan

${ }^{20}$ P.A.F. Lamintang dan C.D. Samosir, Hukum Pidana Indonesia, (Bandung: Sinar Baru, 1983), hal. 130. 
kemudahan dalam mengakses informasi-informasi yang diperlukan namun di sisi lain kemajuan teknologi informasi dan komunikasi juga menjadi suatu sarana yang efektif dalam melakukan suatu perbuatan melawan hukum, baik disadari secara langsung maupun tidak disadari. Masa kini, telah muncul suatu istilah hukum baru yang dikenal sebagai hukum cyber atau cyber law. Secara internasional, peristilahan cyber law digunakan untuk mendefinisikan adanya keterkaitan aturan hukum dengan hal-hal yang berkaitan dengan teknologi informasi dan komunikasi. Sejatinya, Indonesia telah mempunyai aturan hukum yang telah dikodifikasikan dalam bentuk peraturan perundang-undangan untuk mengatur hal-hal yang terkait dengan cyber law itu sendiri, yakni UndangUndang No.19 Tahun 2016 tentang perubahan atas Undang-Undang No. 11 Tahun 2008 tentang Informasi dan Transaksi Elektronik.

Hoge Raad dalam putusannya memberikan adanya pertimbangan bahwa tidak ada perbedaan antara pencemaran secara lisan dengan pencemaran secara tertulis kecuali tuduhan itu telah dilakukan secara lisan atau secara tertulis. Pasal 310 ayat (1) Kitab Undang-Undang Hukum Pidana diklasifikasikan sebagai suatu pencemaran yang dilakukan dengan cara yang bagaimanapun, baik secara lisan maupun secara tertulis. sedangkan Pasal 310 ayat (2) Kitab Undang-Undang Hukum Pidana memberikan hukuman yang lebih berat bagi suatu tindak pencemaran tertentu, yaitu pencemaran yang dilakukan secara tertulis. ${ }^{21}$

Dalam Pasal 310 ayat (3) Kitab Undang-Undang Hukum Pidana, menentukan adanya pengecualian terhadap delik pencemaran dan delik pencemaran tertulis. Menurut terjemahan yang dilakukan oleh Tim Penerjemah Badan Pembinaan Hukum Nasional (BPHN) menerjemahkan bahwa "Tidak merupakan pencemaran atau pencemaran tertulis, jika perbuatan jelas dilakukan demi kepentingan umum atau karena terpaksa untuk membela diri sendiri."22 Pasal 310 ayat (3) Kitab Undang-Undang Hukum Pidana tersebut diterjemahkan juga oleh Lamintang dan Samosir, mereka berpendapat bahwa "Menista dengan lisan ataupun dengan tulisan itu tidak ada, jika pelakunya telah melakukan

\footnotetext{
${ }^{21}$ Ibid., hal.131.

${ }^{22}$ Tim Penerjemah BPHN, Op.Cit., hal.136.
} 
perbuatan tersebut untuk kepentingan umum atau membela diri karena terpaksa." $^{, 23}$

Pasal 310 ayat (3) Kitab Undang-Undang Hukum Pidana merupakan pasal yang dapat meniadakannya sifat melawan hukum atas perbuatan-perbuatan sebagaimana yang telah dirumuskan dalam Pasal 310 ayat (1) dan Pasal 310 ayat (2) Kitab Undang-Undang Hukum Pidana. Oleh karenanya, Pasal 310 ayat (3) Kitab Undang-Undang Hukum Pidana merupakan suatu alasan penghapus pidana (strafuitsluitingsground). ${ }^{24}$ Berdasarkan perspektif teori peniadaan pidana, maka Pasal 310 ayat (3) Kitab Undang-Undang Hukum Pidana ini telah meniadakan unsur dari tindakan si pelaku dalam hal peniadaan kualifikasi kejahatan jika seseorang melakukan tindakan itu berdasarkan kepentingan umum atau melakukan pembelaan diri, karena apabila pelaku terbukti melakukan suatu tindak pidana berdasarkan hal ini, maka putusan hakim berbunyi dibebaskan dari segala tuntutan (onslaag van alle rechtsvervolging) ${ }^{25}$

Pasal 310 ayat (3) Kitab Undang-Undang Hukum Pidana dengan Pasal 27 ayat (3) Undang-Undang No.19 Tahun 2016 dalam kasus putusan No.1047/Pid.Sus/PN.JKT.SEL mempunyai suatu korelasi. Perbuatan yang telah dilakukan oleh terdakwa dalam putusan No.1047/Pid.Sus/PN.JKT.SEL merupakan perbuatan yang disebabkan oleh adanya satu kausalitas yang dibuat oleh pihak yang melaporkan hal ini kepada pihak yang berwajib, sebagaimana teori yang telah dikemukakan oleh Von Buri bahwa akibat yang timbul dari suatu perbuatan pastilah berkaitan erat dengan penyebabnya.

Bella Shofie, yang merupakan seorang public figure telah melaporkan terdakwa Febri Matondang alias Alvin Matondang karena merasa nama baiknya tercemar akibat video yang diunggah oleh terdakwa ke akun sosial Instagram pribadi milik terdakwa. Video yang diunggah oleh terdakwa Alvin Matondang ke dalam akun sosial media Instagram pribadi miliknya bermuatan kata-kata kasar

\footnotetext{
${ }^{23}$ P.A.F. Lamintang dan C.D. Samosir, Op.Cit., hal.130.

${ }^{24}$ Agus Rusianto, Tindak Pidana dan Pertanggungjawaban Pidana, (Jakarta: Kencana, 2016), hal.182.

${ }^{25}$ S.R. Sianturi, Tindak Pidana di KUHP berikut Uraiannya, (Jakarta: Alumni AHMPTHM, 1983) hal. 59.
} 
dan negatif dikarenakan terdakwa Alvin Matondang merasa terhina oleh pernyataan yang diungkapkan oleh Bella Shofie dalam satu wawancara yang dilakukan oleh pihak Bella Shofie terhadap infotaiment televisi swasta, dimana ketika Bella Shofie diwawancara mengenai perannya sebagai wanita Batak dalam film terbaru yang dilakoninya, Bella Shofie memberikan pernyataan bahwa bahwa Bahasa Batak dapat membuat banyak orang merasa illfeel. Jika diterjemahkan ke dalam Bahasa Indonesia, terminologi illfeel merupakan suatu kata sifat yang mewakili perasaan jijik atau muak terhadap suatu hal tertentu.

Pernyataan yang dikemukakan oleh Bella Shofie memenuhi unsur delik yang ada dalam Pasal 156 Kitab Undang-Undang Hukum Pidana. Pasal 156 Kitab Undang-Undang Hukum Pidana menyatakan bahwa "Barangsiapa di muka umum menyatakan perasaan permusuhan,kebencian atau merendahkan terhadap satu atau beberapa golongan rakyat Indonesia, diancam dengan pidana penjara paling lama empat tahun atau pidana denda paling banyak empat ribu lima ratus rupiah." "Perkataan golongan dalam pasal ini dan pasal berikut berarti tiap-tiap bagian dari rakyat Indonesia yang berbeda dengan suatu atau beberapa bagian yang lain karena ras,negeri asal,agama,tempat asal,keturunan,kebangsaan atau kedudukan menurut hukum tata negara." Unsur-unsur formal yang membentuk tindak pidana yang dirumuskan Pasal 156 Kitab Undang-Undang Hukum Pidana adalah sebagai berikut $:^{26}$

1. Perbuatannya :

a) Menyatakan perasaan permusuhan

b) Menyatakan perasaan kebencian

c) Menyatakan perasaan penghinaan

2. Di muka umum

3. Objeknya merupakan golongan penduduk Indonesia

Indonesia merupakan negara yang kaya akan keberagaman suku, kebudayaan,bahasa,dan sistem masyarakat. Tiap masyarakat harus dapat menghormati dan menjunjung tinggi norma-norma yang berlaku, baik norma hukum,norma kesusilaan, norma agama, kebudayaan, dan norma-norma lain yang berlaku. Suku Batak merupakan salah satu bagian dari Indonesia dan berdasarkan

\footnotetext{
${ }^{26}$ Adami Chazawi, Op.Cit., hal. 198 .
} 
analisis singkat yang telah dilakukan, suatu suku merupakan satu kesatuan dengan bahasa, adat-istiadat, sistem kebudayaan, sistem kekeluargaan, dan kemasyarakatan.

Terdakwa Alvin Matondang merupakan salah satu bagian dari suku Batak. Terdakwa merasa tersinggung dan tidak terima oleh ucapan Bella Shofie yang menyatakan bahwa Bahasa Batak dapat membuat masyarakat banyak menjadi illfeel. Oleh karenanya, ia mengunggah video berdurasi 12 detik ke akun Instagram pribadi miliknya untuk mengungkapkan bahwa pernyataan yang dikemukakan oleh Bella Shofie tidaklah benar adanya, hanya saja pemakaian suku kata yang dipakai oleh terdakwa di dalam video yang diunggahnya ke sosial media Instagram pribadi miliknya mengandung unsur delik yang terkandung dalam Pasal 27 ayat (3) Undang-Undang No.19 Tahun 2016, dan oleh karenanya berdasarkan putusan hakim terdakwa mendapatkan sanksi yuridis selama 10 (sepuluh) bulan penjara.

Berdasarkan putusan hakim Pengadilan Negeri Jakarta Selatan terhadap kasus ini, dengan tegas dinyatakan bahwa tedakwa Alvin Matondang terbukti bersalah dan dikenakan sanksi pidana berdasarkan ketentuan yang berlaku dalam Pasal 27 ayat (3) Undang-Undang No.19 Tahun 2016 tentang Perubahan Atas Undang-Undang No.11 Tahun 2008 tentang Informasi Dan Transaksi Elektronik. sedangkan pasal yang menjadi acuan atau dijadikan berlakunya pasal 27 ayat (3) Undang-Undang No.19 Tahun 2016 adalah Pasal 310 Kitab Undang-Undang Hukum Pidana, dimana terdapat 3 (tiga) ayat yang berlaku. Berdasarkan analisis terhadap kasus yang telah dilakukan, perbuatan pidana yang telah dilakukan oleh terdakwa merupakan perbuatan yang mengandung unsur demi kepentingan umum dan juga mengandung unsur membela diri. Hal ini dapat dilihat dari kata-kata "tidak sejelek itu Batak, tahu kau !" dan kata-kata "Bangga aku jadi orang Batak" dalam video yang dijadikan sebagai alat bukti yang pernah diunggah oleh terdakwa dalam akun sosial media Instagram pribadi miliknya.

Pembelaan terdakwa Febri Matondang alias Alvin Matondang terhadap dirinya yang merupakan bagian dari suku Batak itulah melihat bahwa terdakwa tidak mempunyai niat untuk mencemarkan nama baik Bella Shofie, sebagaimana 
hal ini telah dirumuskan dalam Pasal 310 ayat (3) Kitab Undang-Undang Hukum Pidana, dimana yang seharusnya sifat melawan hukum atas perbuatan yang telah dilakukan oleh terdakwa Febri Matondang alias Alvin Matondang seharusnya dihapuskan berdasarkan ketentuan dari pasal tersebut dan juga teori-teori hukum yang berlaku. Analisis terhadap kasus ini diperkuat juga oleh keterangan yang didapatkan berupa data hasil wawancara dengan staff ahli hukum cyber Kementerian Komunikasi dan Informatika, Denden Imadudin Soleh yang menyatakan bahwa perbuatan yang dilakukan oleh terdakwa seharusnya tidak dapat dikenakan sanksi yuridis.

Dalam hukum pidana juga dikenal adanya alasan pembenar. Alasan pembenar dalam suatu tindak pidana dapat meniadakan unsur melawan hukum yang terdapat dalam suatu tindak pidana. Dalam hal ini juga tersirat makna, meskipun perbuatan yang dilakukan oleh seseorang mengandung unsur kesalahan, namun apabila perbuatan yang dilakukan dapat ditinjau dari sudut alasan pembenar, maka orang tersebut dibebaskan dari sanksi yuridis yang akan dibebankan kepadanya. Dapat disimpulkan bahwa walaupun perbuatan yang dilakukan oleh terdakwa Febri Matondang alias Alvin Matondang mengandung unsur kesalahan, akan tetapi perbuatan yang telah terdakwa lakukan tidak seharusnya dikenakan sanksi yuridis, karena perbuatan yang dilakukan oleh terdakwa tersebut merupakan bentuk pembelaan diri atau dengan kata lain, perbuatan yang dilakukan oleh terdakwa bukanlah perbuatan yang melawan hukum. Alasan pembenar juga memperkuat analisis yang telah dilakukan bahwa seharusnya unsur melawan hukum dalam perbuatan yang dilakukan oleh terdakwa dapat dihapuskan dan terdakwa tidak perlu menjalankan sanksi yuridis berupa hukuman penjara sebagai bentuk dari konsekuensi yuridis.

Pada akhirnya, putusan hakim yang dapat menentukan apakah seseorang dinyatakan bersalah atau tidaknya. Hakim dalam memutus suatu perkara harus mempertimbangkan kebenaran yuridis (hukum), kebenaran filosofis (keadilan) dan sosiologis (kemasyarakatan). Seorang Hakim harus membuat keputusan yang adil dan bijaksana dengan mempertimbangkan dampak hukum dan dampak yang 
terjadi dalam masyarakat. ${ }^{27}$ Dari peranan hakim yang sangat penting dan sebagai salah satu penyandang profesi yang sangat terhormat (Officium Nobile), hakim mempunyai tugas untuk menggali, mengikuti, dan memahami nilai-nilai yang hidup dalam masyarakat agar dapat mengenal, merasakan, serta mampu untuk menyelami perasaan hukum dan rasa keadilan yang seharusnya berlaku dalam masyarakat. ${ }^{28}$ Hakim merupakan kongkritisasi hukum dan keadilan yang bersifat abstrak, serta hakim digambarkan sebagai wakil Tuhan di bumi untuk menegakkan hukum dan keadilan. ${ }^{29}$ Konsiderans hakim untuk menjatuhkan sanksi yuridis terhadap terdakwa dalam putusan kasus No.1047/Pid.Sus/PN.JKT.SEL dirasa terlalu memberatkan pihak terdakwa, karena tidak mempertimbangkan faktor kausalitas yang memicu terdakwa melakukan tindak pidana tersebut, serta ketentuan dalam Pasal 310 ayat (3) Kitab Undang-Undang Hukum Pidana merupakan satu pertimbangan atau alasan yang dapat menghapuskan sifat melawan hukum dalam perbuatan pidana yang dilakukan oleh terdakwa Febri Matondang alias Alvin Matondang.

\section{PENUTUP}

\section{A. Kesimpulan}

Berdasarkan uraian analisis yang telah diuraikan di atas, maka dapat ditarik kesimpulan bahwa terdakwa dalam putusan kasus pencemaran nama baik (putusan No.1047/Pid.Sus/B/PN.JKTSEL) Febri Matondang alias Alvin Matondang seharusnya tidak dapat dikenakan sanksi yuridis berupa hukuman penjara, karena walaupun perbuatan yang telah dilakukan oleh terdakwa merupakan suatu kesalahan yang telah memenuhi substansi unsur delik yang terdapat dalam Pasal 27 ayat (3) Undang-Undang No.19 Tahun 2016 sebagaimana Pasal tersebut dijatuhkan oleh hakim terhadap terdakwa, akan tetapi dalam hukum

${ }^{27}$ Barda Nawawi Arief, Bunga Rampai Kebijakan Hukum Pidana, (Jakarta: Kencana, 2014), hal.93.

(1)

${ }^{28}$ Undang-Undang Nomor 4 Tahun 2004 Tentang Kekuasaan Kehakiman, Pasal 28 ayat

29 Al Wisnubroto, Hakim dan Peradilan Di Indonesia, (Yogyakarta: Universitas Atmajaya Yogyakarta, 1997), hal.65. 
pidana mengenal adanya alasan penghapus pidana, yang dapat menghilangkan unsur delik yang ada dalam perbuatan yang telah dilakukan oleh terdakwa Febri Matondang alias Alvin Matondang. Alasan penghapus pidana yang terkait dengan kasus ini diatur di dalam Pasal 310 ayat (3) Kitab Undang-Undang Hukum Pidana, dimana pasal tersebut menyatakan bahwa "Tidak merupakan pencemaran atau pencemaran tertulis, jika perbuatan jelas dilakukan demi kepentingan umum atau karena terpaksa untuk membela diri." Hal ini diperkuat juga oleh beberapa teori-teori maupun asas yang berlaku dalam hukum pidana yang mendukung dalam penulisan jurnal ilmiah, seperti asas geenstrafzonderschuld, atau yang dikenal sebagai asas tiada pidana tanpa adanya kesalahan sebagaimana yang telah diuraikan pada penjelasan sebelumnya.

\section{B. Saran}

Berdasarkan kesimpulan yang telah disimpulkan, maka saran yang dapat diberikan adalah sebaiknya hakim harus lebih berhati-hati serta memperhatikan aspek atau nilai keadilan sebelum memutus suatu perkara. Nilai keadilan yang dimaksudkan disini bukan hanya berfokus pada nilai keadilan yang berlaku bagi masyarakat luas dan juga nilai keadilan bagi korban semata, melainkan juga nilai keadilan bagi pelaku tindak pidana (terdakwa). Salah satu cara untuk mewujudkan nilai keadilan adalah dengan mempertimbangkan hal-hal yang dapat menghapus unsur delik dalam suatu tindak pidana yang dilakukan oleh terdakwa, sebagaimana hal tersebut juga diatur dalam pasal-pasal yang berlaku di dalam Kitab Undang-Undang Hukum Pidana, sebagai contoh kasus No.1047/PidSus/PN.JKT.SEL sebagaimana yang diangkat sebagai bahan kajian dalam jurnal mahasiswa ini, sekiranya hakim dapat mempertimbangkan hal-hal atau karakteristik atas suatu perbuatan yang dapat dihapus unsur deliknya, sebagaimana yang telah dilakukan oleh terdakwa dalam putusan No.1047/PidSus/PN.JKT.SEL unsur deliknya dapat dipertimbangkan untuk dihapuskan yang didasarkan pada ketentuan dari Pasal 310 ayat (3) Kitab Undang-Undang Hukum Pidana. 


\section{DAFTAR PUSTAKA}

\section{A. Buku}

Chazawi, Adami. Hukum Pidana Positif Penghinaan, (Malang: Media Nusantara Creative, 2016). 2011).

Pelajaran Hukum Pidana, (Jakarta: Raja Grafindo Persada,

Hamzah, Andi. Asas-Asas Hukum Pidana, (Jakarta: Rineka Cipta, 2014).

Mertokusumo, Sudikno. Mengenal Hukum Suatu Pengantar, (Yogyakarta: Cahaya Atma Pustaka, 2010).

Nawawi, Barda. Bunga Rampai Kebijakan Hukum Pidana, (Jakarta: Kencana, 2014).

P.A.F. Lamintang dan C.D. Samosir, Hukum Pidana Indonesia, (Bandung: Sinar Baru, 1983).

Raharjo, Agus. Cyber Crime Pemahaman Dan Upaya Pencegahan Kejahatan Berteknologi, (Bandung: Citra Aditya Bakti, 2002).

Rusianto, Agus. Tindak Pidana dan Pertanggung jawaban Pidana, (Jakarta: Kencana, 2016).

Sallesky, Jeff. Spiritualitas Cyberspace, Bagaimana Teknologi Komputer Mempengaruhi Kehidupan Keberagaman Manusia, (Bandung: Mizan, 1999).

Sianturi, S.R. Tindak Pidana di KUHP berikut Uraiannya, (Jakarta: Alumni AHM-PTHM, 1983).

Sutiksno, Filsafat Hukum Bagian 1, (Jakarta: Balai Pustaka, 2013).

Sutiyoso, Bambang. Metode Penelitian Hukum, (Yogyakarta: UII Press, 2015).

Wisnubroto, Al. Hakim dan Peradilan Di Indonesia, (Yogyakarta: Universitas Atmajaya Yogyakarta, 1997).

\section{B. Peraturan Perundang-undangan Nasional}

Indonesia, Kitab Undang-Undang Hukum Pidana dan Kitab Undang-Undang Hukum Acara Pidana, Jakarta: Rineka Cipta, 2014.

,Kitab Undang-Undang No. 19 Tahun 2016 Tentang Perubahan Atas Undang-Undang No. 11 Tahun 2008 Tentang Informasi Dan Transaksi Elektronik, Surabaya: Kesindo Utama, 2017.

, Kitab Undang-Undang No. 4 Tahun 2004 Tentang Kekuasaan Kehakiman, Jakarta: Tamita Utama, 2004.

\section{PutusanPengadilan}

Indonesia, Putusan Pengadilan Negeri Jakarta Selatan No.1047/PID.SUS/2016/PN.JKT.SEL. 
D. Artikel Internet

Anonim, "Makalah Sejarah Perkembangan Internet di Dunia", https://docs.google.com/document/d/1qCNWAFBXQvyfk2fygSB00o6w8n 9z-VNxNUFrTs2Osvk/edit?pli=1\#heading =h.gjdgxs.

Portal Berita Bintang, https://www.bintang.com/celeb/read/2373417/versus-bellashofie-alvin-matondang-saya-bukan-haters.

Portal Hukum Universitas Bina Nusantara, http://businesslaw.binus.ac.id/2016/07/31/kejahatan-dengan-menggunakan-saranateknologi-informasi/ .

Portal Berita Teknologi KOMPAS, "Sejarah dan Perkembangan Internet", http://teknologi.kompasiana.com/internet/2014/07/02/sejarah-danperkembangan-internet661863.html .

Portal Berita Teknologi KOMPAS, http://tekno.kompas.com/read/2016/10/24/15064727/2016.pengguna.inte rnet.di.indonesia.capai.132.juta . 